Old Dominion University

ODU Digital Commons

Physics Faculty Publications

Physics

$10-2018$

\title{
Solutions for Fermi Questions, October 2018: Question 1: Automobile Air Conditioning; Question 2: Falling Leaves
}

Larry Weinstein

Old Dominion University, lweinste@odu.edu

Follow this and additional works at: https://digitalcommons.odu.edu/physics_fac_pubs

Part of the Physics Commons, and the Science and Mathematics Education Commons

\section{Repository Citation}

Weinstein, Larry, "Solutions for Fermi Questions, October 2018: Question 1: Automobile Air Conditioning; Question 2: Falling Leaves" (2018). Physics Faculty Publications. 255.

https://digitalcommons.odu.edu/physics_fac_pubs/255

\section{Original Publication Citation}

Weinstein, L. (2018). Solutions for Fermi questions, October 2018: Question 1: Automobile air conditioning; Question 2: Falling leaves. Physics Teacher, 56(7), A489-A489. doi:10.1119/1.5055310

This Article is brought to you for free and open access by the Physics at ODU Digital Commons. It has been accepted for inclusion in Physics Faculty Publications by an authorized administrator of ODU Digital Commons. For more information, please contact digitalcommons@odu.edu. 


\section{Solutions for Fermi Questions, October 2018: Question 1: Automobile air conditioning; Question 2: Falling leaves}

Larry Weinstein

Citation: The Physics Teacher 56, A489 (2018); doi: 10.1119/1.5055310

View online: https://doi.org/10.1119/1.5055310

View Table of Contents: http://aapt.scitation.org/toc/pte/56/7

Published by the American Association of Physics Teachers

\section{Articles you may be interested in}

Answer to October Figuring Physics

The Physics Teacher 56, A422 (2018); 10.1119/1.5055309

Solution to March 2018 Challenge: The march of the electrons

The Physics Teacher 56, B489 (2018); 10.1119/1.5055311

SOLAR MEASUREMENTS

The Physics Teacher 56, 422 (2018); 10.1119/1.5055318

Mysterious soda can

The Physics Teacher 56, 420 (2018); 10.1119/1.5055314

Analyzing Railguns with Excel: Simple Numerical Integration for the Classroom

The Physics Teacher 56, 436 (2018); 10.1119/1.5055324

Question 1: Automobile air conditioning; Question 2: Falling leaves

The Physics Teacher 56, 489 (2018); 10.1119/1.5055342

\section{Make the Switch: Modular Circuits

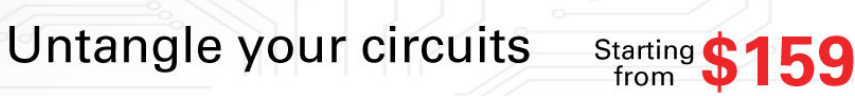
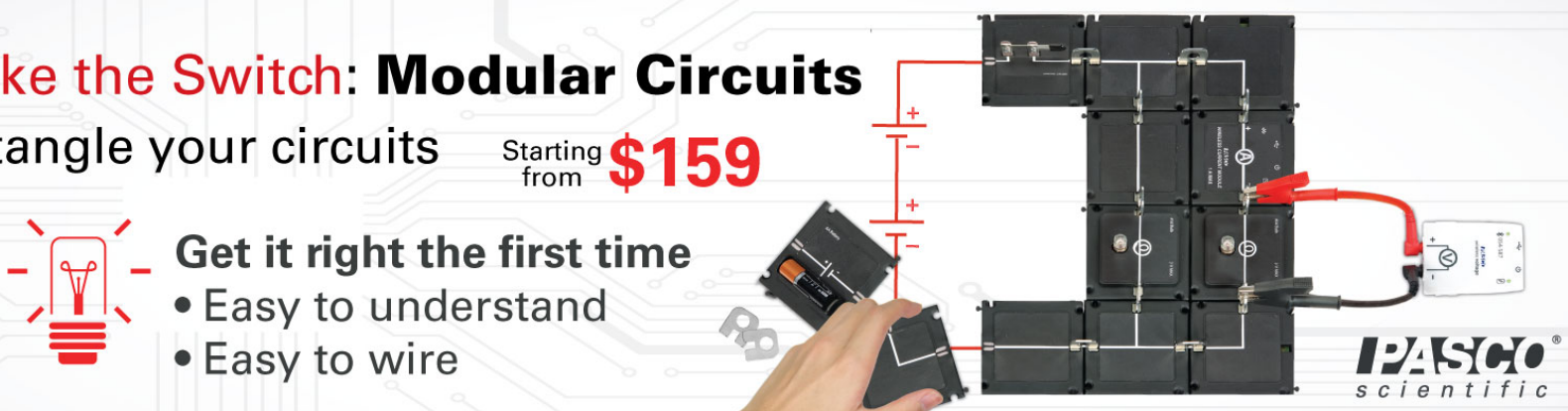


\section{Fermi Questions}

\section{Solutions for Fermi Questions, October 2018}

\section{Duestion 1: Automobile air condition- ing}

How much does it cost to air condition all American automobiles for a year? (Thanks to Alex Godunov of

Old Dominion University for suggesting the question.)

Answer: To estimate this, we need to estimate the number of cars, the amount of time that they use AC each year, and the cost using the AC. There are $3 \times 10^{8}$ Americans and not quite one car per person, giving $2 \times 10^{8}$ cars. The average car is driven about $10^{4}$ miles per year (based on car warranties) at an average speed of $30 \mathrm{mph}$ (faster than 10 and slower than $100 \mathrm{mph}$ or faster than 20 and slower than $60 \mathrm{mph}$ [faster in Montana and slower in Los Angeles]). Thus, the average car is driven about 300 hours per year (which is reasonable, since that is about one hour per day). We could try to estimate the fraction of driving time spent using AC by considering drivers in Kansas City, Seattle, New Orleans, etc., but that is needlessly complicated. The fraction of driving time spent using AC will be more than $10 \%$ and less than $100 \%$ (even in New Orleans), giving an estimate of $30 \%$. This means that each car uses its AC 100 hours per year.

Now let's estimate the cost per hour of running the AC. We'll start by estimating its power consumption. A typical window air conditioner for a home consumes a maximum of $1500 \mathrm{~W}$ (or it's likely to overload the electrical circuit) and cools an entire room. Therefore, a car air conditioner will use between $10 \%$ and $100 \%$ of that, for an estimated power consumption of $500 \mathrm{~W}$. (That's about 2/3 Horsepower.)

That means that the $\mathrm{AC}$ will consume a total energy $E_{\text {total }}=N P t=\left(2 \times 10^{8}\right)(500 \mathrm{~W})(100 \mathrm{hr})=10^{10} \mathrm{~kW}$-hr. At typical electrical rates of $\$ 0.1 / \mathrm{kW}-\mathrm{hr}$, that is $\$ 1$ billion of energy. Wow! That's a lot of money!

Or is it? That's the cost for all of the 200 million cars in the entire country. The cost per car is only $\$ 5$. Even if gasoline energy is twice as expensive as electrical energy, that would only be $\$ 10$ of gasoline per car.

Who cares? Compared to the cost of operating a car, the cost of its air conditioning is negligible. If you turn off the $\mathrm{AC}$ and open the windows, increased drag will probably cost at least as much (but we'll estimate that in a future column).

Copyright 2018, Lawrence Weinstein.

\section{Question 2: Falling leaves}

How many leaves will fall in the United States this fall?

Answer: To estimate this, we need to estimate the area of the United States, the fraction of that area covered by trees, and the number of leaves per area. The United States is about 3000 miles $(5000 \mathrm{~km})$ from East to West (based on either 6 hours of airplane flight at $500 \mathrm{mph}$ or 3 time zones which is $3 / 24$ of the Earth's circumference). It is about half that from North to South, giving an area of

$$
A=l w=\left(5 \times 10^{3} \mathrm{~km}\right)\left(2 \times 10^{3} \mathrm{~km}\right)=10^{7} \mathrm{~km}^{2} \text {. }
$$

We could add another $30 \%$ for Alaska (more than $10 \%$, less than $100 \%)$, but why bother?

The fraction covered by trees will be more than $10 \%$ and less than $100 \%$, so we will estimate $30 \%$, giving a forested (or at least treed) area of $3 \times 10^{6} \mathrm{~km}^{2}$.

Now we need to estimate the leaf density. We could estimate the tree density, the size of each tree, the number of limbs, branches, twigs, etc, and the number of leaves per twig, but that is needlessly complicated. Let's simplify this. Go stand under a tree and look up. It's OK, I'll wait. What is the average number of leaves over any point? The number of leaves over any point covered by the tree will be more than one and less than ten, giving an average leaf coverage of three.

Now we only need to estimate the size of the average leaf. The average leaf will have an area of more $10 \mathrm{~cm}^{2}$ $\left(2 \mathrm{in}^{2}\right.$ ) and less than $100 \mathrm{~cm}^{2}$ (the palm of my hand), giving an estimated area of $30 \mathrm{~cm}^{2}$. Thus, the total number of leaves on all the trees in the United States is

$$
N=\frac{3\left(3 \times 10^{6} \mathrm{~km}^{2}\right)}{30 \mathrm{~cm}^{2}}\left(10^{10} \mathrm{~cm}^{2} / \mathrm{km}^{2}\right)=3 \times 10^{15} .
$$

That's a LOT of leaves (3 quadrillion). Does this make sense?

Let's check this number for sanity. There are an estimated $3 \times 10^{12}$ trees in the world. With $5 \%$ of the surface area, this would give the U.S. $2 \times 10^{11}$ trees, with about $10^{4}$ leaves per tree. This is not crazy. Alternatively, if you own a house on a half-acre (1/4 hectare) lot and it is $30 \%$ treed, then you will end up raking $n=\frac{3\left(10^{3} \mathrm{~m}^{2}\right)}{30 \mathrm{~cm}^{2}}\left(\frac{10^{4} \mathrm{~cm}^{2}}{\mathrm{~m}^{2}}\right)=10^{6}$ leaves every fall. This is also not crazy. Wow. Three quadrillion leaves really do fall on the United States every fall. Who knew?

Copyright 2018, Lawrence Weinstein. 